\title{
Estimation of Catch Efficiency and Chum Salmon Abundance by Parallel Gillnet Experiment
}

\author{
Yukimasa Ishida* \\ (Accepted July 16, 1985)
}

\begin{abstract}
Parallel gillnet experiments were carried out in order to estimate catch efficiency of gillnet and abundance of chum salmon in the central Bering Sea in July, 1984. In the experiment, two gillnets were simultaneously set in parallel configuration at a distance of about $2 \mathrm{~km}$, and the catch in number of saimon by each side of each gillnet was recorded. Release and recovery experiments were also conducted to estimate the moving speed of salmon. In order to estimate catch efficiency and density of fish, data were analyzed based on a model that takes into account the moving speed of fish and the catch interaction between two parallel gillnets. A relationship between CPUE (number $/ \tan$ ) and density (number $/ \mathrm{km}^{2}$ ) was constructed, and CPUE at each station was converted into density. The density was weighted by the size of the survey area, and the abundance of chum salmon was calculated.
\end{abstract}

Pacific salmon are generally anadromous and return to their natal rivers to spawn when they mature. Due to this characteristic, stock assessment and management of salmon are mainly based on the data collected in coastal waters and rivers. For example, the catch plus escapement in coastal waters and rivers is regarded as the index of population abundance, which is used in stockrecruitment relationships analyzed for population management. ${ }^{1}$ But salmon production (that is increase of biomass) mainly take place in offshore and oceanic waters. Density-dependent survival and growth in the ocean have been reported for some salmon stocks, ${ }^{2-4)}$ and salmon carrying capacity of the North Pacific Ocean became an important consideration relating to salmon enhancement. $^{8,8)}$ Furthermore, salmon fisheries in the North Pacific Ocean have been carried out in specific fishing areas and seasons. The following major questions have been raised, relevant to salmon population biology in the sea: (1) How many salmon utilize the offshore environment in specific times and spaces? (2) What is the origin of these salmon? (3) What is the effect of the salmon fisheries in offshore waters on the salmon stocks?

To address these problems, extensive studies have been carried out in the North Pacific Ocean for nearly 30 years, and much biological information of Pacific salmon has been accumulated. But estimation of salmon abundance at sea, especially absolute abundance in offshore waters, has scarce- ly been attempted. In this study, parallel gillnet experiment was designed, based on a simple model, and carried out to estimate the catch efficiency of gillnet and the abundance of salmon in offshore waters. Release and recovery experiment was also conducted in order to estimate the moving speed of the fish which is one of the essential parameter for the present analysis.

\section{Methods}

\section{Model for Parallel Gillnet Experiment}

A schematic diagram of the parallel gillnet experiment for chum salmon is shown in Fig. 1.7) The assumptions of the model are as follows: 1) Moving direction of fish is mainly at right angles to the gillnets and the number of fish moving parallel to the net is negligible. 2) Moving speed of fish is constant during the period of nets soaked. 3) The fish distribute mainly in the surface layer corresponding to the depth of the gillnet. 4) The effective area of the gillnet is determined by the length of gillnets, moving speed of the fish, and time between set and haul of the gillnet.

Notations used in this model are as follows:

$M_{1}$ number of chum caught by side 1 of maingillnet

$M_{2}$ number of chum caught by side 2 of maingillnet

$\mathrm{S}_{1}$ number of chum caught by side 1 of subgillnet

*! Far Seas Fisheries Research Laboratory, Orido, Shimizu 424, Japan (石田行正：遠洋水産研究所). 


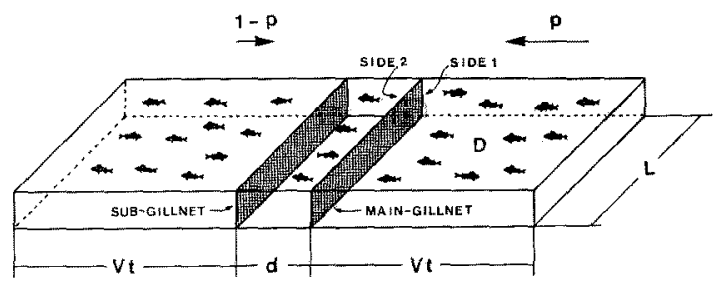

Fig. 1. A schematic diagram of the parallel gillnet experiment.

$\mathrm{S}_{2} \quad$ number of chum caught by side 2 of subgillnet

L mean length of gillnet estimated at time of set and haul, as the gear is shaped in the water $(\mathrm{km})$

$\mathrm{t}$ time between set and haul (h)

d distance between main- and sub-gillnet at time of set $(\mathrm{km})$

$\mathrm{V}$ moving speed of chum $(\mathrm{km} / \mathrm{h})$

$\mathrm{p}$ ratio of chum moving in predominant direction

$\kappa \quad$ catch efficiency of gillnet

D density of chum (number $/ \mathrm{km}^{2}$ )

The gillnet with the larger catch is defined as main-gillnet and the other as sub-gillnet. Also, side 1 of the gear is the side facing the fish swimming in the predominant direction and is the side of the main-gillnet with the larger catch; the other side of the gear is considered to be as side 2 .

The numbers of chums caught by side 1 of each gillnet are expressed as follows:

$$
\begin{aligned}
& \mathbf{M}_{1}=\mathrm{LVtDp} \kappa \\
& \mathrm{S}_{1}=\mathrm{LdDp} \kappa+\mathrm{L}(\mathrm{Vt}-\mathrm{d}) \mathrm{Dp}(1-\kappa) \kappa
\end{aligned}
$$

Substituting (1) into (2), the efficiency of the gear, $\kappa$, can be calculated as:

$$
\kappa=\left(1-S_{1} / M_{1}\right) /(1-d / V t)
$$

The ratio of chums moving in the predominant direction is determined as follows:

$$
\mathrm{p}=\mathrm{M}_{1} /\left(\mathrm{M}_{1}+\mathrm{S}_{2}\right)
$$

Substituting the results of (3) and (4) into (1), density is calculated as:

$$
\mathrm{D}=\mathrm{M}_{1} /(\mathrm{LV} \operatorname{tp} \kappa)
$$

From the data of the parallel gillnet experiment, catch per unit effort (CPUE) of an ordinary single gillnet set is estimated as follows:

$$
\text { CPUE }=\left(\mathrm{M}_{1}+\mathrm{S}_{2}\right) / \text { number of gillnet in } \tan ^{* 1}
$$

\section{Field Survey}

The experiment was conducted by the two research vessels Wakatake maru and Hokuho maru at 14 stations in the central Bering Sea in July, 1984 (Fig. 2). Each gillnet in the parallel experiments was 150 tans (about $7.5 \mathrm{~km}$ ) in length, that is, 10 tans of $124 \mathrm{~mm}$ stretch mesh size, 30 tans of research gillnet with 10 different mesh sizes (3 tans for each mesh size from 48 to $157 \mathrm{~mm}$ ), 100 tans of $121 \mathrm{~mm}$ mesh net, and 10 tans of $124 \mathrm{~mm}$ mesh net.

The nets were sets at about 1800 and hauled at about 0600 local time. The time between set and haul of the gillnet was determined as the average duration from set to haul of each end of the parallel gillnet. Direction of setting was north-south at stations 1 to 9 depending upon the direction of migration of chums, as suggested by past tag release-recovery data. At stations 10 to 25 , except 13 , the set direction was changed to northeast-southwest, so that the nets were more at right angles to the migratory direction of chums, which had been suggested by the circle experiments.*2 At Station 13, nets were set in a northwest-southeast direction because of rough weather. Distance between two gillnets was kept at about $2 \mathrm{~km}$ at time of set. The shape and position of the gillnets in the water at time of set and haul were obtained from the track chart of vessels, and length of gillnets in the water and their drifting direction and speed were estimated.

The state of entanglement was observed for the 100 tans of $121 \mathrm{~mm}$ mesh nets from the foredeck of the vessels at time of haul, and the numbers of fish entangled by species and by side of net were recorded. The number of fish caught was also recorded by species for each 5 tans of $121 \mathrm{~mm}$ mesh net and for each 3 tans of 10 different mesh sizes.

(6) The moving speed of chums (V) was estimated

*1 "tan" is a unit of gillnet and $1 \tan$ of gillnet is about $50 \mathrm{~m}$ in length.

*2 A total of 300 tans of gillnet was set in circle at stations 10 and 13, and the state of entanglement of salmon was observed. 


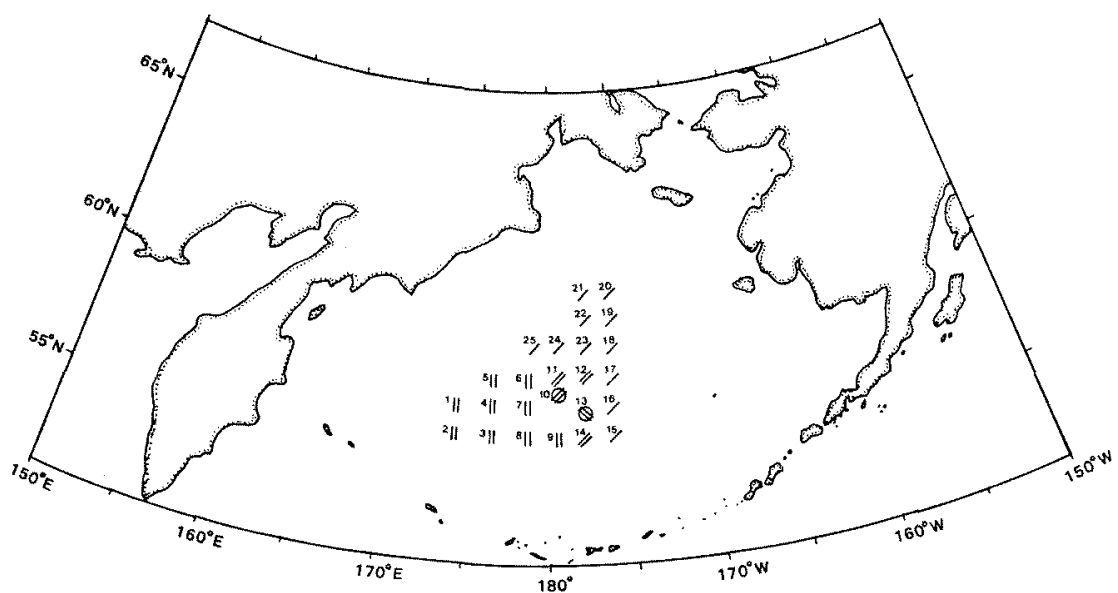

Fig. 2. Stations of experimental fishing operation in the central Bering Sea in July, 1984. Parallel bars indicate the parallel gillnet fishing and single bars indicate the single gillnet fishing. Two circles indicate the circle set fishing. Direction of each bar indicates the net setting direction.

from tag release and recovery experiment. A total of 1320 chum caught by long-line was tagged and released in 1984, and 17 chum among them were recovered in the Bering Sea in this fishing season. Linear distance between release and recovery positions and the days travelled were calculated from these data.

\section{Results}

\section{Parallel Gillnet Experiment}

The position of gillnets at time of set and haul are shown in Fig. 3. At Station 1, position of eastern gillnet at time of haul was roughly estimated because the estimation procedure was still being developed. From these figures, it is shown that gillnets drifted eastward at southwestern stations (St. 1, 2, 3, 4, 5, 7, 8, 9, and 10) and westward at northeastern stations (St. 11, 12, 13, and 14). Maximum drifting distance about $10 \mathrm{~km}$ were observed at St. 13 and 14 with drifting speed of about $0.9 \mathrm{~km} / \mathrm{h}$. These figures indicate that the position and shape of gillnets changed during the time between set and haul, but that the two gillnets generally maintained parallel configuration.

Chum catches in number in each 5 -tan segment of gillnet are shown in Fig. 4. These indicate the structure of chum schools encountering the nets. At Station 5, the trend of catch was similar between the main- and sub-gillnets. At other stations, such close similarity was not observed, but there were no clear discrepancies in the trend of catch between two gillnets. These results suggest that the parallel gillnets caught fish of the same schools moving through the sampled area.

The fork length frequencies of chum caught in the parallel gillnet experiment are shown in Fig. 5 . The gillnet-caught chum were mainly in the range of 50 to $60 \mathrm{~cm}$ in fork length. The mean fork length of chum in the main-gillnet was significantly larger than that of fish in the sub-gillnet at stations $4,5,7$ and 8 , and the opposite result was observed at Station 3. However, there were no clear differences in mean fork length between the two gillnets at other stations.

The numbers of chum caught by each side of two gillnets are shown in Table 1. In the northsouth set at stations 1 through 9 , the main-gillnets (with the larger catches) were located at the eastern position, except at Station 3. At stations 10 through 14, where gillnets were set roughly in an east-west direction, the larger catches were made by the southern gillnet. These results suggest that chum moved mainly in a northwesterly direction. Chum caught by the same side of two gillnets are thought to have been moving in the same direction. The fish moving in the predominant direction were caught by side 1 of two gillnets. The side 1 catches decreased from the main- to the sub-gillnet by ratios of $S_{1} / M_{1}$ ranging from 0.34 to 0.89 (mean $=0.64$ ). On the other hand, catches by side 2 of the two gillnets were of fish moving in the opposite direction. Side 2 catches decreased from the sub- to the main- 


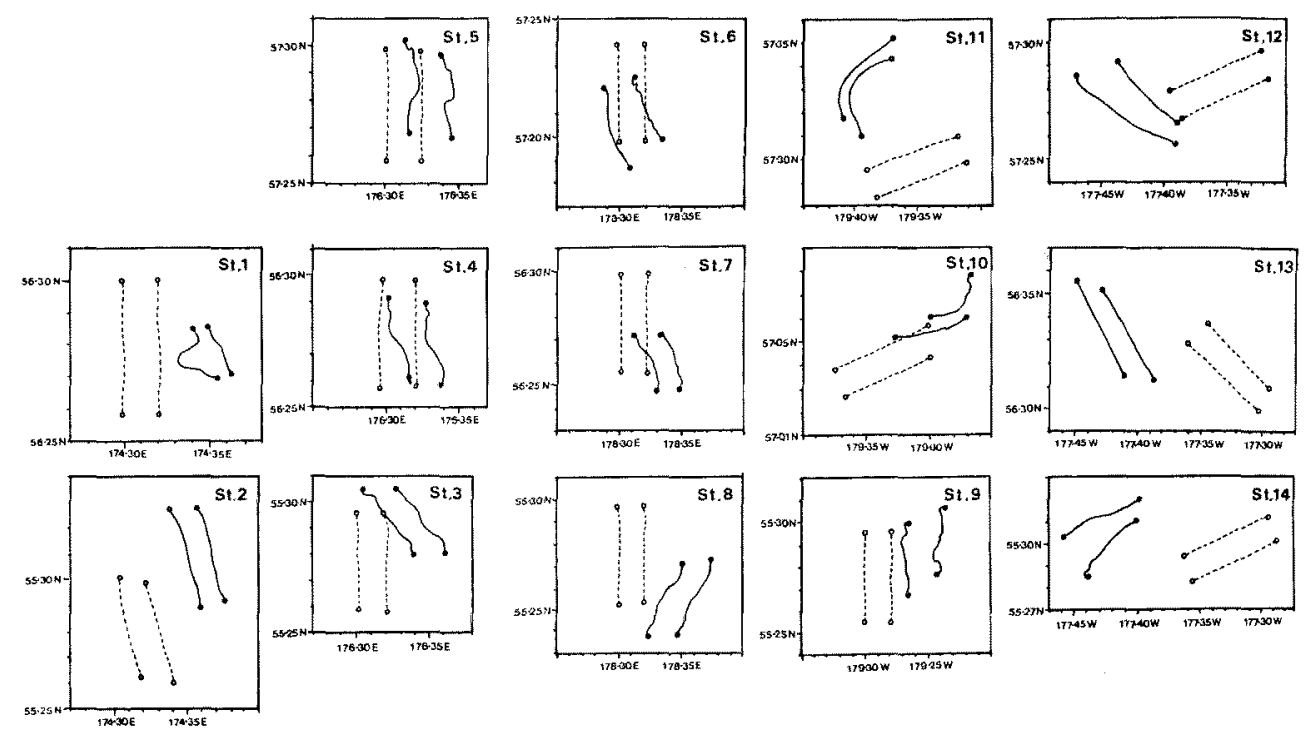

Fig. 3. Position and shape of parallel gillnets at time of set (dashed line) and haul (solid line).

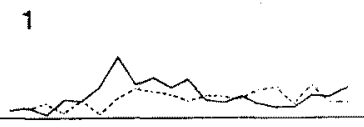

2

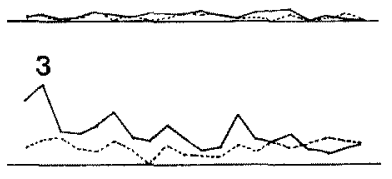

4
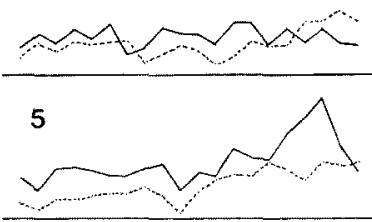

6

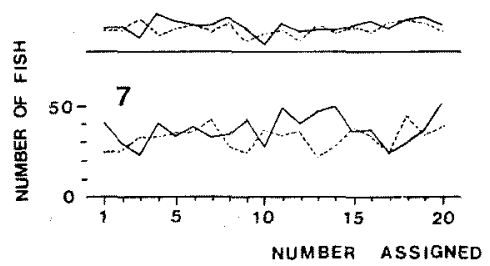

8

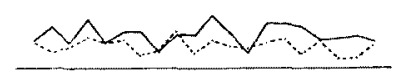

9

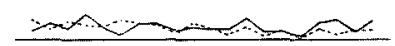

10

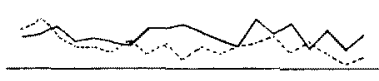

11

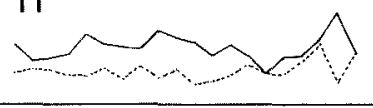

12

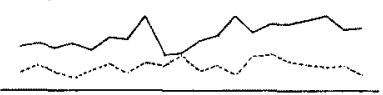

13

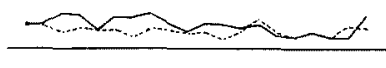

14

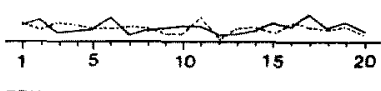

Fig. 4. Catch in number of chum salmon every 5 tans of $121 \mathrm{~mm}$ mesh gillnets. Solid and dashed lines indicate the catch by main-gillnet and sub-gillnet, respectively. 

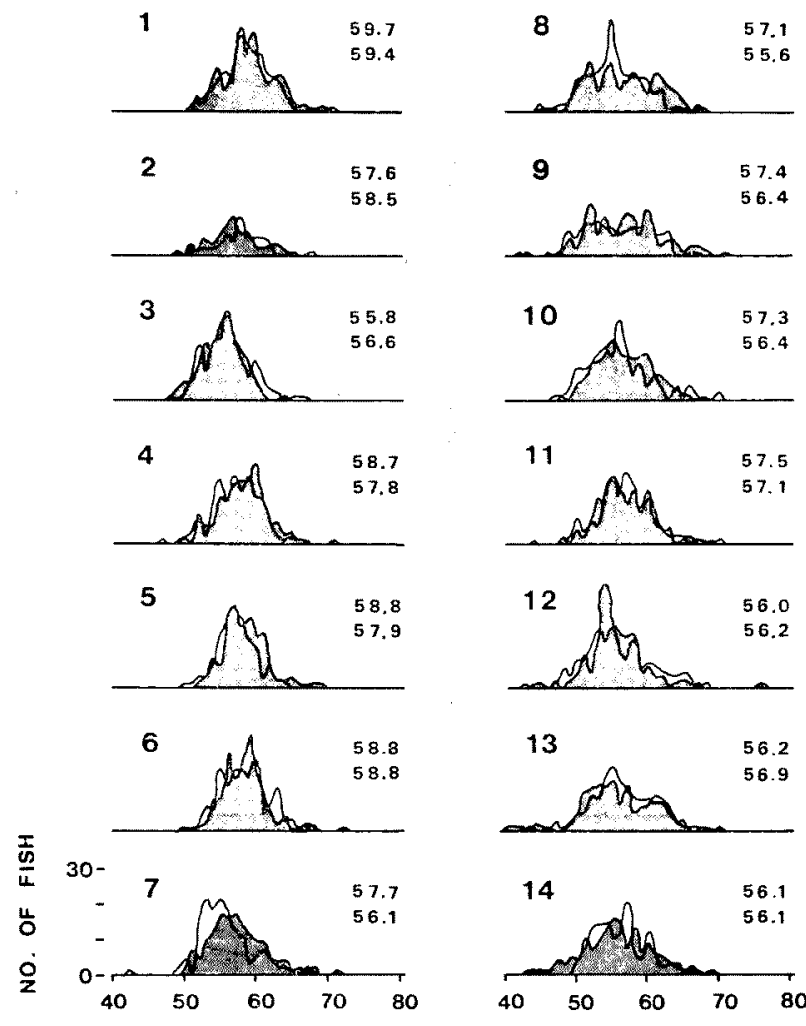

FORK LENGTH IN CM

Fig. 5. Fork length frequencies of chum salmon caught by each station. Dotted frequencies are for main-gillnet and the others for sub-gillnet. Upper figures indicate the mean length by main-gillnet and lower one for sub-gillnet.

Table 1. The number of chum salmon caught by each side of two gillnets in the parallel experiment

\begin{tabular}{|c|c|c|c|c|c|c|c|c|c|}
\hline \multirow{3}{*}{ Station } & \multirow{3}{*}{ Date } & \multirow{3}{*}{$\begin{array}{l}\text { Setting } \\
\text { direction }\end{array}$} & \multirow{3}{*}{$\begin{array}{c}\text { Position } \\
\text { of } \\
\text { Main- } \\
\text { net }\end{array}$} & \multicolumn{4}{|c|}{ Number of chums } & \multirow{2}{*}{\multicolumn{2}{|c|}{ Decreasing ratio }} \\
\hline & & & & \multicolumn{2}{|c|}{ Main-net } & \multicolumn{2}{|c|}{ Sub-net } & & \\
\hline & & & & $\begin{array}{l}\text { Side } 1 \\
\left(M_{1}\right)\end{array}$ & $\begin{array}{c}\text { Side } 2 \\
\left(\mathrm{M}_{2}\right)\end{array}$ & $\begin{array}{c}\text { Side } 1 \\
\left(\mathrm{~S}_{1}\right)\end{array}$ & $\begin{array}{c}\text { Side } 2 \\
\left(\mathrm{~S}_{2}\right)\end{array}$ & $\mathrm{S}_{1} / \mathrm{M}_{1}$ & $\mathrm{M}_{2} / \mathrm{S}_{2}$ \\
\hline 1 & July 2 & N-S & $E$ & 207 & 46 & 140 & 71 & 0.68 & 0.65 \\
\hline 2 & July 3 & N-S & $\mathrm{E}$ & 63 & 2 & 43 & 8 & 0.68 & 0.25 \\
\hline 3 & July 4 & $\mathrm{~N}-\mathrm{S}$ & W & 293 & 65 & 151 & 42 & 0.52 & 1.55 \\
\hline 4 & July 5 & N-S & $\mathbf{E}$ & 340 & 86 & 291 & 66 & 0.86 & 1.30 \\
\hline 5 & July 7 & N-S & $\mathrm{E}$ & 580 & 59 & 316 & 66 & 0.54 & 0.89 \\
\hline 6 & July 8 & $\mathbf{N}-\mathbf{S}$ & $\mathbf{E}$ & 250 & 30 & 158 & 91 & 0.63 & 0.33 \\
\hline 7 & July 9 & N-S & $E$ & 638 & 107 & 536 & 157 & 0.84 & 0.68 \\
\hline 8 & July 10 & $\mathbf{N}-\mathbf{S}$ & $\mathbf{E}$ & 313 & 56 & 167 & 75 & 0.53 & 0.75 \\
\hline 9 & July 11 & $\mathbf{N}-\mathbf{S}$ & $\mathbf{E}$ & 117 & 20 & 104 & 23 & 0.89 & 0.87 \\
\hline 10 & July 13 & ENE-WSW & $\mathbf{S}$ & 314 & 52 & 207 & 46 & 0.66 & 1.13 \\
\hline 11 & July 14 & ENE-WSW & $\mathbf{S}$ & 574 & 57 & 308 & 67 & 0.54 & 0.85 \\
\hline 12 & July 15 & ENE-WSW & $\mathbf{S}$ & 511 & 105 & 218 & 61 & 0.43 & 1.72 \\
\hline 13 & July 17 & NW-SE & $\mathbf{S}$ & 121 & 131 & 103 & 113 & 0.85 & 1.16 \\
\hline 14 & July 18 & ENE-WSW & $\mathbf{S}$ & 137 & 18 & 46 & 98 & 0.34 & 0.18 \\
\hline
\end{tabular}


Table 2. Data of chum salmon released and recovered in the Bering Sea in July 1984

\begin{tabular}{|c|c|c|c|c|c|c|}
\hline \multicolumn{2}{|c|}{ Date } & \multicolumn{2}{|c|}{ Position } & \multirow{2}{*}{$\begin{array}{l}\text { Number } \\
\text { of days }\end{array}$} & \multirow{2}{*}{$\begin{array}{c}\text { Linear } \\
\text { distance } \\
(\mathrm{km})\end{array}$} & \multirow{2}{*}{$\begin{array}{l}\text { Apparent } \\
\text { speed } \\
\text { (km/day) }\end{array}$} \\
\hline Release & Recovery & Release & Recovery & & & \\
\hline July 4 & July 13 & $55^{\circ}-30^{\prime} \mathrm{N}, 176^{\circ}-30^{\prime} \mathrm{E}$ & $57^{\circ}-06^{\prime} \mathrm{N}, 176^{\circ}-57^{\prime} \mathrm{E}$ & 9 & 179.9 & 20.0 \\
\hline July 5 & July 7 & $56^{\circ}-30^{\prime} \mathrm{N}, 176^{\circ}-30^{\prime} \mathrm{E}$ & $56^{\circ}-59^{\prime} \mathrm{N}, 175^{\circ}-51^{\prime} \mathrm{E}$ & 2 & 66.7 & 33.4 \\
\hline July 5 & July 7 & $56^{\circ}-30^{\prime} \mathrm{N}, 176^{\circ}-30^{\prime} \mathrm{E}$ & $56^{\circ}-54^{\prime} \mathrm{N}, 175^{\circ}-51^{\prime} \mathrm{E}$ & 2 & 59.6 & 29.8 \\
\hline July 5 & July 14 & $55^{\circ}-31^{\prime} \mathrm{N}, 176^{\circ}-32^{\prime} \mathrm{E}$ & $56^{\circ}-31^{\prime} \mathrm{N}, 175^{\circ}-13^{\prime} \mathrm{E}$ & 9 & 138.0 & 15.3 \\
\hline July 7 & July 8 & $57^{\circ}-31^{\prime} \mathrm{N}, 176^{\circ}-33^{\prime} \mathrm{E}$ & $57^{\circ}-29^{\prime} \mathrm{N}, 176^{\circ}-25^{\prime} \mathrm{E}$ & 1 & 8.8 & 8.8 \\
\hline July 7 & July 8 & $57^{\circ}-31^{\prime} \mathrm{N}, 176^{\circ}-33^{\prime} \mathrm{E}$ & $57^{\circ}-24^{\prime} \mathrm{N}, 176^{\circ}-25^{\prime} \mathrm{E}$ & 1 & 15.2 & 15.2 \\
\hline July 7 & July 8 & $57^{\circ}-30^{\prime} \mathrm{N}, 176^{\circ}-32^{\prime} \mathrm{E}$ & $57^{\circ}-24^{\prime} \mathrm{N}, 176^{\circ}-25^{\prime} \mathrm{E}$ & 1 & 13.1 & 13.1 \\
\hline July 7 & July 8 & $57^{\circ}-30^{\prime} \mathrm{N}, 176^{\circ}-32^{\prime} \mathrm{E}$ & $57^{\circ}-24^{\prime} \mathrm{N}, 176^{\circ}-25^{\prime} \mathrm{E}$ & 1 & 13.1 & 13.1 \\
\hline July 7 & July 8 & $57^{\circ}-30^{\prime} \mathrm{N}, 176^{\circ}-32^{\prime} \mathrm{E}$ & $57^{\circ}-20^{\prime} \mathrm{N}, 176^{\circ}-25^{\prime} \mathrm{E}$ & 1 & 19.8 & 19.8 \\
\hline July 7 & July 8 & $57^{\circ}-30^{\prime} \mathrm{N}, 176^{\circ}-32^{\prime} \mathrm{E}$ & $57^{\circ}-59^{\prime} \mathrm{N}, 178^{\circ}-07^{\prime} \mathrm{E}$ & 1 & 108.2 & $108.2^{*}$ \\
\hline July 9 & July 11 & $56^{\circ}-30^{\prime} \mathrm{N}, 178^{\circ}-32^{\prime} \mathrm{E}$ & $56^{\circ}-20^{\prime} \mathrm{N}, 178^{\circ}-11^{\prime} \mathrm{E}$ & 2 & 28.4 & 14.2 \\
\hline July 9 & July 12 & $56^{\circ}-24^{\prime} \mathrm{N}, 178^{\circ}-34^{\prime} \mathrm{E}$ & $56^{\circ}-10^{\prime} \mathrm{N}, 178^{\circ}-40^{\prime} \mathrm{E}$ & 3 & 26.7 & 8.9 \\
\hline July 9 & July 12 & $56^{\circ}-24^{\prime} \mathrm{N}, 178^{\circ}-34^{\prime} \mathrm{E}$ & $56^{\circ}-10^{\prime} \mathrm{N}, 178^{\circ}-40^{\prime} \mathrm{E}$ & 3 & 26.7 & 8.9 \\
\hline July 9 & July 12 & $56^{\circ}-24^{\prime} \mathrm{N}, 178^{\circ}-34^{\prime} \mathrm{E}$ & $56^{\circ}-21^{\prime} \mathrm{N}, 179^{\circ}-36^{\prime} \mathrm{E}$ & 3 & 63.8 & $21.3^{*}$ \\
\hline July 9 & July 13 & $56^{\circ}-30^{\prime} \mathrm{N}, 178^{\circ}-32^{\prime} \mathrm{E}$ & $56^{\circ}-05^{\prime} \mathrm{N}, 178^{\circ}-35^{\prime} \mathrm{E}$ & 4 & 46.4 & 11.6 \\
\hline July 9 & July 13 & $56^{\circ}-30^{\prime} \mathrm{N}, 178^{\circ}-32^{\prime} \mathrm{E}$ & $56^{\circ}-09^{\prime} \mathrm{N}, 178^{\circ}-03^{\prime} \mathrm{E}$ & 4 & 49.0 & 12.3 \\
\hline July 12 & July 17 & $57^{\circ}-05^{\prime} \mathrm{N}, 179^{\circ}-19^{\prime} \mathrm{W}$ & $56^{\circ}-47^{\prime} \mathrm{N}, 178^{\circ}-40^{\prime} \mathrm{E}$ & 5 & 126.7 & 25.3 \\
\hline
\end{tabular}

* Asterisk indicates the recovery by the mothership.

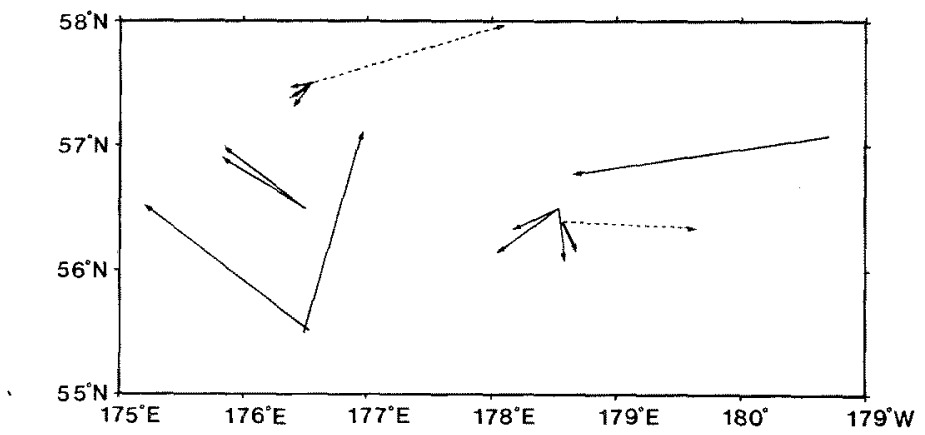

Fig. 6. Recoveries of 17 chum salmon released in the Bering Sea in July, 1984. Solid arrows indicate the recoveries by catcher boats and the dashed arrows indicate the recoveries by mortherships. Thick arrows indicate more than two recoveries.

gillnet at nine stations out of fourteen, by ratios of $\mathrm{M}_{2} / \mathrm{S}_{2}$ ranging from 0.18 to 0.89 (mean $=0.61$ ); however, $\mathbf{M}_{2}$ exceeded $\mathbf{S}_{2}$ at other five stations.

\section{Release and Recovery Experiment}

Tag release and recovery data for chum in the Bering Sea in July 1984 are shown in Table 2. Fifteen chum were recovered by catcher boats and two other fish were recovered on motherships and therefore could not be identified their exact recovering positions. The number of days between release and recovery ranged from one to nine days, and the linear distance between release and recovery positions varied from 8.8 to 179.9 $\mathrm{km}$. Calculated moving speed, excluding the two morthership recoveries, varied from 8.8 to 33.4 $\mathrm{km} /$ day.

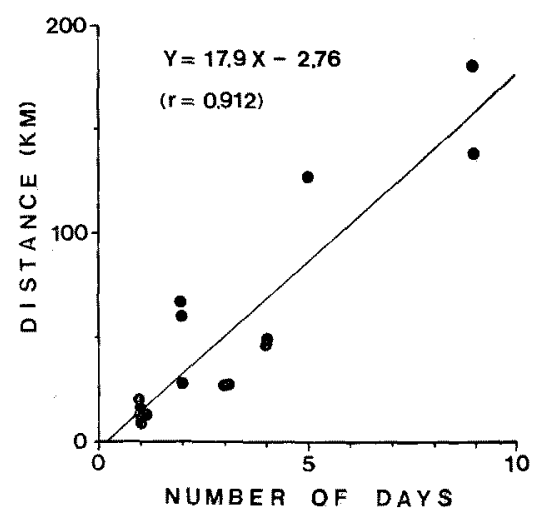

Fig. 7. Relationship between number of days and distance travelled from release to recovery points. Data from catcher boat recoveries. 
Table 3. Experimental values and parameters of the parallel gilinet fishing experiment. $p$ is ratio in dominant moving direction, $\kappa$ is catch efflciency of gillnet, $D$ is density of chums in number per $\mathrm{km}^{2}$, and CPUE is catch in number per tan

\begin{tabular}{crrrrrrrrrrr}
\hline Station & $\mathbf{M}_{\mathbf{1}}$ & \multicolumn{1}{c}{$\mathbf{S}_{1}$} & \multicolumn{1}{c}{$\mathrm{S}_{2}$} & $\mathrm{~L}$ & $\mathrm{~d}$ & $\mathrm{t}$ & $\mathrm{p}$ & \multicolumn{1}{c}{$\mathrm{r}$} & $\mathrm{D}$ & CPUE \\
\hline 1 & 207 & 140 & 71 & 3.8 & 2.1 & 11.7 & 0.75 & 0.43 & 19.6 & 2.78 \\
2 & 63 & 43 & 8 & 4.8 & 2.2 & 12.4 & 0.89 & 0.42 & 3.8 & 0.71 \\
3 & 293 & 151 & 42 & 4.2 & 2.1 & 12.2 & 0.88 & 0.63 & 13.9 & 3.35 \\
4 & 340 & 291 & 66 & 4.4 & 2.5 & 12.5 & 0.84 & 0.20 & 50.0 & 4.06 \\
5 & 580 & 316 & 66 & 4.5 & 2.3 & 12.7 & 0.90 & 0.60 & 25.1 & 6.46 \\
6 & 250 & 158 & 91 & 4.5 & 2.2 & 12.3 & 0.73 & 0.48 & 17.0 & 3.41 \\
7 & 638 & 536 & 157 & 4.6 & 2.1 & 12.5 & 0.80 & 0.21 & 89.4 & 7.95 \\
8 & 313 & 167 & 75 & 5.0 & 2.2 & 12.1 & 0.81 & 0.62 & 13.9 & 3.88 \\
9 & 117 & 104 & 23 & 4.4 & 2.2 & 12.9 & 0.84 & 0.14 & 22.8 & 1.40 \\
10 & 314 & 207 & 46 & 4.3 & 2.3 & 10.8 & 0.87 & 0.48 & 21.7 & 3.60 \\
11 & 574 & 308 & 67 & 4.9 & 2.3 & 11.2 & 0.90 & 0.64 & 24.4 & 6.41 \\
12 & 511 & 218 & 61 & 4.9 & 2.3 & 11.6 & 0.89 & 0.78 & 17.2 & 5.72 \\
13 & 121 & 103 & 113 & 5.0 & 2.2 & 11.1 & 0.52 & 0.20 & 27.8 & 2.34 \\
14 & 137 & 46 & 98 & 4.9 & 2.2 & 11.7 & 0.58 & 0.89 & 6.2 & 2.35 \\
\hline Mean & & & & 4.6 & 2.2 & 12.0 & 0.80 & 0.48 & 25.2 & 3.89 \\
\hline
\end{tabular}

The release and recovery positions of 17 chum are shown in Fig. 6. The high seas recovery of tagged fish was limited to the areas where catcher boats operated, so the indicated migratory direction might be biased somewhat. However, most fish were recovered west of the released positions. These data suggest that chums generally moved in westward direction, which corroborates results from the parallel gillnet experiment.

The relationship between the number of days and distance travelled from release to recovery positions is shown in Fig. 7 for only catcher boats recoveries. The distance the fish moved increased with number of days after release and a significant correlation was observed between them. An apparent swimming velocity of $17.9 \mathrm{~km} /$ day $(=0.75$ $\mathrm{km} / \mathrm{h}$ ) was estimated by linear regression.

\section{Estimation of Catch Efficiency and Chum Salmon Abundance}

Summary data from the parallel gillnet experiment, estimates of ratio of chums moving in the predominant direction, catch efficiency of gillnet, density and CPUE of chum are shown in Table 3. Although the total length of 100 tans of 121 $\mathrm{mm}$ mesh gillnet was about $5.0 \mathrm{~km}$, the actual average length $(L)$ in the water was less than $5 \mathrm{~km}$ because the state of the gillnet reduced the effective length. Distance (d) between two gillnets was fixed about $2.2 \mathrm{~km}$ at the time of set. The time ( $\mathrm{t}$ ) from set to haul varied from 10.8 to $12.9 \mathrm{~h}$ depending upon the conditions at fishing operations and averaged $12.0 \mathrm{~h}$. The ratio (p) of chum moving in the

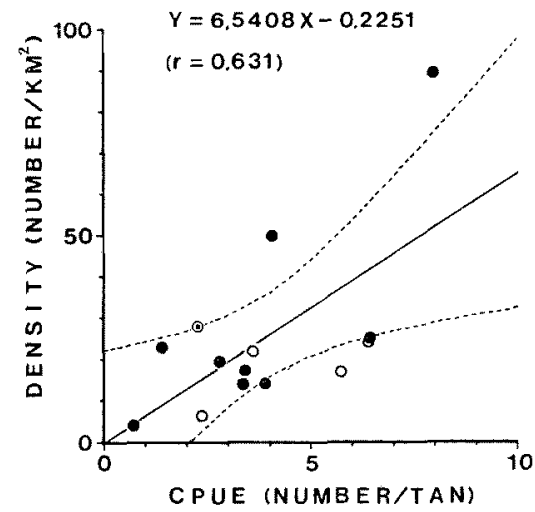

Fig. 8. Relationship between CPUE (number/tan) and fish density (number $/ \mathrm{km}^{2}$ ). Solid data points indicate the values at stations 1 through 9 and open data points indicate the values at stations 10 through 14 except 13 that is indicated by double data point. Dashed lines indicate the $95 \%$ confidence limit.

predominant direction was about 0.8 except at stations 13 and 14, where the predominant direction was not observed clearly. Estimates of catch effciency $(\kappa)$ of gillnet ranged from 0.14 to 0.89 and averaged 0.48. Average catch efficiencies were 0.41 at stations 1 through 9 , and 0.70 at stations 10 through 14 except 13. The difference between these two values was significant and seemed to be caused by the difference of net setting direction. Density of chum ranged from 3.8 to $89.4 \mathrm{fish} / \mathrm{km}^{2}$ and averaged $25.2 \mathrm{fish} / \mathrm{km}^{2}$. CPUE values varied 


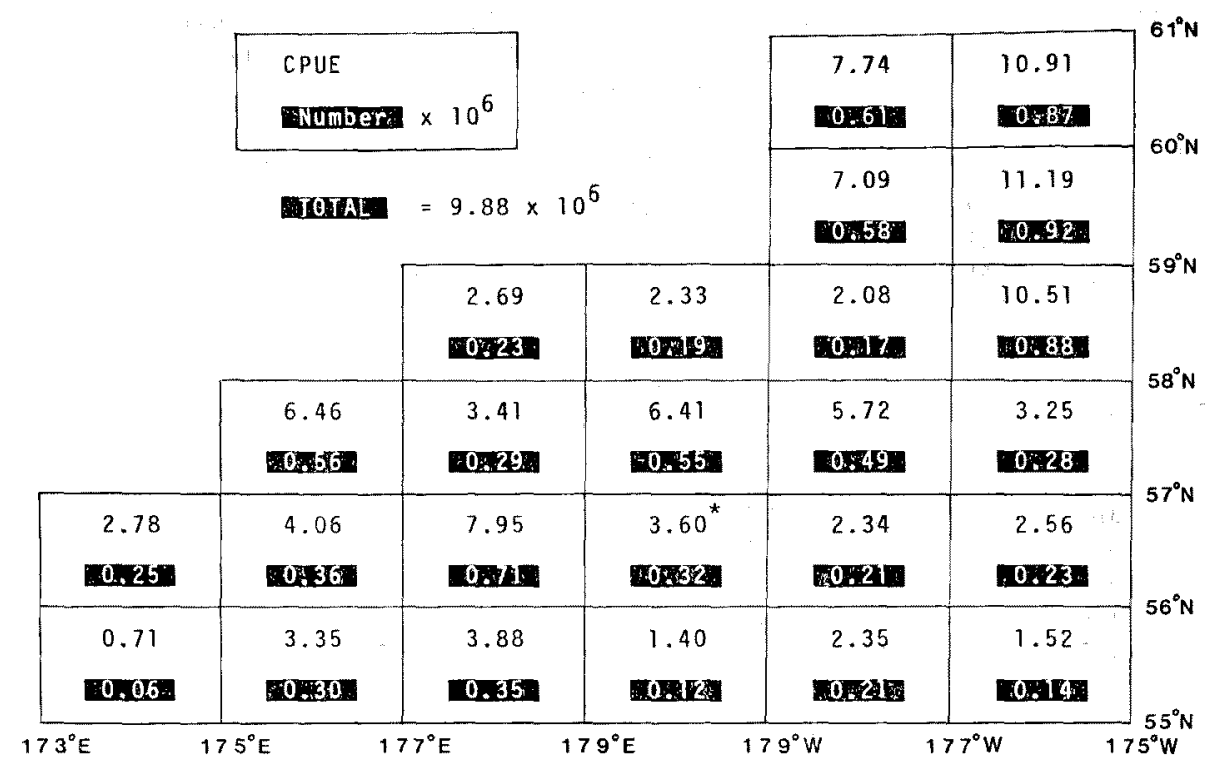

Fig. 9. CPUE (number/tan) and population estimations $\left(\times 10^{\circ}\right)$ of chum salmon by $1^{\circ} \times 2^{\circ}$ area in the Bering Sea. Asterisk indicates the tentative value because the actual fishing operation was carried out in the northern part of this area.

from 0.71 to $7.95 \mathrm{fish} / \mathrm{tan}$ and averaged $3.89 \mathrm{fish} /$ tan.

The relationship between CPUE (X) and density (Y) of chum salmon is shown in Fig. 8. The regression line based on 9 data points from stations 1 through 9 was: $Y=8.7222 X-4.5616$ $(r=0.756)$. That based on 4 data points from stations 10 through 14 except 13 was: $Y=3.1548 X$ $+3.1153(r=0.738)$. There is no significant difference between these two regression lines, so all data were pooled and the following regression line was estimated: $Y=6.5408 \mathrm{X}-0.2251$ $(\mathrm{r}=0.631)$. This relationship was used to convert CPUE values to fish densities in the following step, although the estimates of density showed a large variation even at a similar CPUE level.

Population estimates of chums by $1^{\circ} \times 2^{\circ}$ area are shown in Fig. 9. CPUE value was converted into fish density by the above relationship. Estimated fish density was weighted by the size of a $1^{\circ} \times 2^{\circ}$ area, and the total number of chum in the sampled area was calculated. CPUE varied from 0.71 to 11.19 fish/tan depending upon the area. The total number of chum in the sampled area was calculated to have been $9.88 \times 10^{\circ}$.

\section{Discussion}

The model used in this study is based on several assumptions that simplify the ecological aspects of salmon in the high seas. It is important to examine how these simplifications affect the estimates of each parameter and to determine what kind of improvement should be made in the model and in the field survey.

\section{Moving Direction}

The moving direction of chum is assumed to be at right angles to the gillnet in the present model. If this assumption is not fulfilled sufficiently, a fish school that does not encounter the first gillnet might be caught by the second gillnet. This will make $S_{1}$ large and the catch efficiency of the gillnet, $\kappa$, will be underestimated. This is probably the reason why the average $\kappa$ value at stations 1 to 9 , where nets were set in a north-south direction, was smaller than that at stations $10,11,12$ and 14 , where moving direction of chums was taken into account.

The moving direction also affects the effective area of the gillnet and CPUE values. In the present model, effective area is defined as a rectangle given by $\mathrm{LVt}$. If moving direction is $\theta$ degrees $\left(0^{\circ}<\theta<90^{\circ}\right)$ to the gillnet, the actual effective area becomes a parallelogram given by LVt $\sin \theta$. Regardless of net setting direction, the effective area is assumed as a rectangle in the present analysis, so fish density would be under- 
estimated in the case of $\theta$ less than $90^{\circ}$. CPUE values will be also underestimated because effective length of gillnet is reduced to $L \sin \theta$. It would be necessary to assess the moving direction by means of two gillnets set at right angles to each other with non-interactive distance.

\section{Moving Speed}

Information on moving speed of salmon in the high seas has been investigated by tagging and biotelemetry. ${ }^{\text {9-12) }}$ Tagging data give the minimum moving speed depending on the duration of days up to recovery, because the straight distance between release and recovery points is used as the distance travelled. It is reported that moving speed of chums based on tagging was 17-39 nautical miles/day $(1.3-3.0 \mathrm{~km} / \mathrm{h})$ in the central Bering Sea. ${ }^{g}$ In the case of chum released near Adak Island and recovered in the northern Bering Sea, moving speed of maturing chums was 15-66 $\mathrm{km} /$ day $(0.6-2.8 \mathrm{~km} / \mathrm{h})$ and that of immature was $13-44 \mathrm{~km} /$ day $(0.5-1.8 \mathrm{~km} / \mathrm{h}) .{ }^{10}$ Based on biotelemetric data, moving speed along the real swimming route of chums was estimated as 4.4 $4.7 \mathrm{~km} / \mathrm{h}$ off Etorofu Island and about $0.87-5.43$ $\mathrm{km} / \mathrm{h}$ off the Okhotsk coast. ${ }^{11,12)}$

For the present model, apparent moving speed estimated by tagging experiment, i.e. $17.9 \mathrm{~km} /$ day $=0.75 \mathrm{~km} / \mathrm{h}$, is applied as $\mathrm{V}$ mentioned in the definition section, because the migrating speed is mainly areal and seasonal specific issues. If the moving speed is underestimated, fish density will be overestimated in the formula (5) and vice versa. Accumulation of tag recovery data in a short period is necessary to improve the estimates of moving speed of salmon on the high seas. Also, it would be possible to estimate the moving speed of salmon by the experiment with three gillnets set in parallel configuration.

\section{Vertical Distribution and Diel Movement}

Vertical distribution is another important ecological aspect of salmon on the high seas that affects capture by gillnets. By the fishing with gillnet at five layers from surface to $50 \mathrm{~m}$ in the northwest Pacific and Bering Sea in summer, salmon were caught mostly in the top of $10 \mathrm{~m}$ and their number sharply decreased at the deeper layers, although slight differences were found between species. ${ }^{13)}$ In the northwestern Gulf of Alaska, it is reported that sockeye and chums ascend toward the surface during the night and descend during the daytime. ${ }^{14}$ Diel change of catch was also observed by repeated fishing operation during one day and number of chum caught by gillnet varied even during the night. ${ }^{15)}$

The estimate of abundance by gillnet catches only reflects the fish distributed in the surface layer, because the depth of gillnets used in this study is only about $5 \mathrm{~m}$ in the water. Furthermore, if assumption of constant effectiveness of gillnet during the time between set and haul was in conflicted with real situation due to the diel change mentioned above, it will affect the effective area of gillnet and the estimates of fish density as a results. It would be necessary to assess the effective fishing period of net by repeated fishing operation.

\section{Mesh Selectivity of Gillnet and Dropout}

Catch by gillnet with a given mesh size makes a specific body length composition rather than real one in the water. The relative efficiencies for each body length to a given mesh size are presented by a unimodal curve called the selectivity curve. The shape of this curve depends on fish species and stage of maturation. In the case of $121 \mathrm{~mm}$ mesh gillnet, chum salmon ranging from 50 to $60 \mathrm{~cm}$ in fork length indicate high relative efficiencies more than $50 \%{ }^{18,17}$ ) The fork length frequencies in Fig. 5 are biased from the frequencies in the population by mesh selectivity. Based on the data from the research gillnet with 10 different mesh sizes conducted in this survey, three modes were observed at around 34,45 and $55 \mathrm{~cm}$ in fork length, ${ }^{* 1}$ and these roughly correspond to $0.1,0.2$ and 0.3 year-old fish, respectively. ${ }^{* 2}$ It would, therefore, be possible to reconstract the unbiased estimates in term of the mesh selectivity by using the data from the research gillnet at the next stage.

Another problem is the non-catch losses, including dropout and predation. The rates of dropout plus predation were reported rather high values. ${ }^{18)}$ These losses will reduce the catch and, as a result, fish density and CPUE will be underestimated in formula (5) and (6), respectively. It would be also necessary to take into account these factors in the future analysis.

\section{Acknowledgments}

The author wishes to express his sincere gra-

*1 Author's unpublished data.

*2 Freshwater age preceeds dot; ocean age follows dot. 
titude to Dr. I. Ikeda of Far Seas Fisheries Research Laboratory, Fisheries Agency of Japan, for his invaluable suggestion concerning the parallel gillnet experiments and reviewing the manuscript. The author is also deeply indebted to Dr. S. Odate of Tokai Regional Fisheries Research Laboratory and Mr. K. Takagi of Far Seas Fisheries Research Laboratory, Fisheries Agency of Japan, for their interest and encouragement, and Mr. C. K. Harris of Fisheries Research Institute, University of Washington, for his valuable comments in reviewing the manuscript. Thanks are due to many generous people for their useful suggestions during this study: Messrs. S. Kawasaki, J. Ito, S. Ito, Y. Shimazu, S. Kawahara, Y. Uozumi, T. Ichii and K. Hiramatsu of Far Seas Fisheries Research Laboratory and Mr. S. Hase of Fisheries Agency of Japan. Thanks are also due to Mr. Y. Hattori, the captain of Wakatake maru, Mr. M. Hatazawa, the captain of Hokuho maru, and crews of both vessels who gave great cooperation during the field survey in the Bering Sea.

\section{References}

1) W. E. Ricker: J. Fish. Res. Board Can., 11, 559623 (1954).

2) D. E. Rogers: in "Salmonid Ecosystems of the North Pacific" (ed. by W. J. McNeil and D. C. Himsworth), Oregon State Univ. Press, Oregon, 1980, pp. 267-283.

3) R. M. Peterman: J. Fish. Res. Board Can., 35,
1434-1450 (1978).

4) R. M. Peterman: Can. J. Fish. Aquat. Sci, 41, 1825-1829 (1984).

5) F. Favorite and T. Laevastu: NWAFC Proc. Rep., 79-16, 1-47 (1979).

6) T. Honkalehto: NWAFC Proc. Rep., 84-19, 123 (1984).

7) A. I. Treschev: Rapp. P.-v. Réun. Cons, int, Explor. Mer, 168, 54-57 (1975).

8) H. Kondo, Y. Hirano, N. Nakayama, and M. Miyake: Int. North Pac. Fish. Comm. Bull., 17, 1-213 (1965).

9) T. Yonemori: Bull. Far Seas Fish. Res. Lab., 4, 51-69 (1971).

10) F. Neave, T. Yonemori, and R. G. Bakkala: Int. North Pac. Fish. Comm. Bull, 35, 1-79 (1976).

11) T. Ichihara, T. Yonemori, and H. Asai: Bull. Far. Seas Fish. Res. Lab., 13, 63-77 (1975).

12) T. Ichihara and A. Nakamura: in "Proceedings of the North Pacific Aquaculture Symposium" (ed. by B. R. Melteff and R. A. Nevé), Univ. Alaska, 1982, pp. 39-49.

13) S. Machidori: Bull, Hokkaido Reg. Fish. Res. Lab., 31, 11-17 (1966).

14) J. I. Manzer: J. Fish. Res. Board Can., 21, 891903 (1964).

15) S. Mishima and K. Shimazaki: Bull. Fac. Fish, Hokkaido Univ., 20, 5-21 (1969).

16) T. Ishida: Int. North Pac. Fish. Comm. Bull., 26, 1-11 (1969).

17) K. Takagi and T. Ishida: Bull. Far Seas Fish. Res. Lab., 5, 161-176, (1971).

18) W. E. Ricker: J. Fish. Res. Board Can., 33, 14831524 (1976). 